\title{
Editorial
}

\section{The BP Deepwater Horizon débâcle and corporate brand exuberance}

John M.T. Balmer

is professor of Corporate Marketing and Director of the Centre of Research in Marketing, Brunel University, London; Quondam Professor of Corporate Brand/Identity Management, Bradford University School of Management, UK.

Journal of Brand Management (2010) 18, 97-104. doi:10.1057/bm.2010.33; published online 29 October 2010

\section{GETTING IN TO DEEPWATER: BP'S SODDEN CORPORATE BRAND PROMISE?}

Of course, reminding senior executives of an organisation that, 'I warned you', is a patently difficult observation to make and a painful remark to hear. Academics must of course be mindful of the immense challenges a CEO faces in running a corporation and in being the custodian of the corporate brand (Balmer, 1995) - it is a far from easy task, and statements of this type by academics need to be accompanied by humility and not hubris.

However, as the BP Deepwater Horizon imbroglio has played out over the last few months I have been minded of my observations of 10 years earlier when I voiced some concern over BP's new corporate brand positioning: a positioning that was, to me, well-intentioned, but misguided; a corporate brand positioning that - for the last 10 years or more - has emphasised BP's environmental, good corporate citizen and green credentials.

To me, this was - and is - an example of what I call Brand Exuberance. BP's brand positioning was, at best, an aspiration and was, in truth, never really attainable; to a large degree, it was divorced from reality. For instance, over recent years BP's safety record has not been without blemish, and BP's apparent obfuscation in detailing the size of the Deepwater oil-leak and the injudicious comments of its CEO are more akin to Brand Indifference. I will speak more of this later.

One key point I wish to make here is that although the acquisition of a strong and favourable corporate brand can result in considerable strategic leverage, if it is not handled correctly there can be difficulties leading to strategic weakness. As such, it is important to ensure that - among concerns - such a corporate brand positioning is subject to ongoing senior management scrutiny and, perhaps, subject to scenario planning (Balmer, 1995).

Corporate brand positioning requires hard thinking and not wishful thinking.

However - as readers of this journal will surely know all too well - this is not enough. This is because corporate brands are not about what is said but, moreover, about what is lived and, as I have argued for some time, what customer and stakeholder communities believe about a corporate brand; they have emotional ownership of the corporate brand. Sight of this must not be lost (Balmer, 2008, 2009a).

Moreover, the BP Deepwater disaster provides a timely reminder that senior managers, and their advisors, need to ensure 
that their corporate brands are effectively monitored and managed, and managed at a senior level. Moreover, they need to ensure that brand-positioning strategies are reliable (based on an organisation's identity anchors - in terms of what an entity does, including its operational philosophy and organisational purpose, that is shareholder/ stakeholder value). Of course, the ACID Test framework (Balmer et al, 2009; Balmer, 2001b) can be a useful diagnostic framework by which corporations can test that their key identity types are in alignment, and this includes - in the context of the ACID Test - its corporate brand: 'the covenanted identity'.

\section{THE GREENING AND OILING OF BP: 1998-2010}

Returning to BP, I am reminded that just over 10 years ago, in the aftermath of the 1998 merger between what was then known as British Petroleum and the USbased Amoco oil company, a new global, a decidedly less British and unequivocally more American, entity emerged that espoused a new brand proposition based on its green credentials. Emphasising this point, Lord Browne (BP's inspirational former CEO), back in November 2001, characterised to us, in a key-note address delivered at the Eighth International Corporate Identity Group (ICIG) Symposium in London, that the BP corporation was: 'global with British roots and headquarters' (Balmer and Greyser, 2002).

My analysis then - using the ACID Test of corporate identity/brand management alignment - revealed a potentially hazardous gap between corporate reality (BP's Actual Identity) and the aspirations of the corporation's senior executives (BP's Desired Identity). This analysis of $\mathrm{BP}$ was, as my students of that time will recall, a prominent feature of my MBA electives on corporate brand/corporate marketing management during that period, and was given a wider voice in a co-authored article with Professor Greyser of Harvard Business School in our article in the California Management Review of 2002. This is what we said:

BP's recent (post-merger) corporate positioning strategy emphasised its environmental activities and aspirations (Desired Identity). However, to many this seems to be at variance with organisational reality and the Actual Identity of the organisation. BP is quintessentially concerned with oil exploration, refining, and distribution. The environmental activist group Greenpeace, for instance, pointed out that only 1 per cent of BP's activities come from sustainable sources. It is clear from the above that the postmerger BP - which may be less British and more American, and certainly more global in outlook - has not changed its core business. Although BP has a stated corporate aim of being green-orientated, this environmental positioning (Desired Identity) is an aspiration which (to us) bears arguably questionable resemblance to nearterm reality; BP's substantive ability to achieve its Desired Identity is constrained, but it may be able to achieve meaningful relative "green" advantage over other energy firms. (Balmer and Greyser, 2002)

\section{CORPORATE BRAND EXUBERANCE}

The recent BP environmental disaster in the Gulf of Mexico has, again, brought into sharp relief the inherent tensions between organisational responsibility and corporate profitability, shareholder and stakeholder concerns and the dangers of what I call, in institutional contexts, corporate brand exuberance.

What do I mean by corporate brand exuberance?

To me, this is where a brand positioning strategy - although it may be well intentioned - is somewhat unrealistic, if not fanciful.

In the aftermath of BP's merger with the US-based oil company Amoco in 1998 - and 
applying the ACID Test Corporate Identity/ Branding framework - it became clear that the newly merged company's corporate brand positioning was, potentially, perilous. This was because the corporation adopted a new strategy that extolled its green credentials via corporate communications and advertising campaigns. It adopted a logo that reinforced its environmental aspirations - a pastel-shaded sunburst - and the corporation was no longer to be known as British Petroleum but 'bp': its lower case initials aimed to communicate that the organisation was non-corporate, friendly, self-effacing, green and, demonstrably, it played down its British credentials.

As readers of The Journal of Brand Management may recall, BP formally denoted British Persian that, originally, reflected the bi-national interests of the company; then BP stood for British Petroleum and, post the 1998 merger, BP was to stand for something quite different: 'Beyond Petroleum', a brand positioning based on the courageous - but ultimately disastrous - notion that the company wished to assert its environmental and green credentials, including a concern with sustainable energy sources. Four branddrivers for BP were developed by Landor (the prominent US-based brand and identity consultancy). Clay Timon, the Chairman of Landor, identified Landor's four drivers for BP: 'progressive, performance, green and innovative' (Bakan, 2005, p. 26). Corporate brand consultancies can also occasionally be harbingers of corporate brand exuberance.

\section{REFLECTING ON THE BP - DEEPWATER, EXXON VALDEZ, PIPER ALPHA AND ONGOING NIGER-DELTA DISASTERS}

To me, corporate brand catastrophes are context-specific in terms of their organisational and brand impact. Time and place will determine the degree of damage - or not - that will be caused. Although an analysis of the above may well reveal the degree of negative response, the best response is, of course, for organisations to act in a responsible manner. In this regard, I primarily consider the examples of the BP Deepwater disaster, but also draw on other analogous catastrophes: Exxon Valdez, The Piper Alpha Oil rig and Africa's ongoing, and conveniently forgotten, Niger Delta catastrophe. I list a number of 'corporate branding traps' along with some observations regarding corporate brand catastrophes.

(a) The CEO's personality may acquire the default position of being the corporate brand personality: an anthropomorphising of the corporate personality. Although some company owners actively seek to directly imbue the corporate brand personality with their persona - Sir Richard Branson (Virgin), Bill Gates (Microsoft), Dame Anita Roddick (Body Shop) - this remains, for the main, atypical among CEOs. However, in crisis situations - as the BP case has shown - the CEO may be accorded a default position: Tony Hayward (CEO of BP) found himself in this position and, to many in the United States, he was not only the voice of BP but was, de facto, BP. The Economist noted that for 28 years Hayward had been a successful BP employee but also noted: 'When the microphones were on, gaffes gushed from his lips. He was a walking public relations disaster and had to go.' (The Economist, 2010a).

(b) Stakeholder power can trump shareholder power. This is not the place to embark on the ongoing debate regarding stakeholder power versus shareholder power, but the $\mathrm{BP}$ case reveals that account needs to be taken of both; in certain instances, the former will trump the latter: consider the decision of BP not to award 
dividend payments to shareholders in the aftermath of the Deepwater débâcle. Perhaps the lesson here is that, while the mind of the corporation should focus on shareholders, its heart should be mindful of stakeholders.

(c) The appropriation of corporate brand catastrophes and perceived country of origin effects. In the United States, BP has, sometimes over recent months, been portrayed as a British company. In the United Kingdom, the belief, by some, that senior figures in the US administration - and media - had uttered excoriating and, at times, vituperative comments regarding the Britishness of $\mathrm{BP}$ as a means of deflecting any accusation of US culpability in permitting such hazardous activities to take place in US waters was wounding.

To me, observing the above was an example of brand crisis appropriation. The upshot was a deterioration of Anglo-US relations, and a good deal of deft, if not intense, governmental and diplomatic footwork took place to calm further troubled waters. BP, for its part, clearly had to take account of the perception in the United States that it was a British aka alien, corporation, and it soon became apparent that its blank global canvas had to have a more pronounced US hue. At first sight this is curious, as BP, post its merger with Amoco in 1998, gave birth to, in truth, a global company and is almost every bit as much a US as it is a British company.

What has this to do with brand management? Well, to me, this is a salient reminder that country of origin - or perceived country of origin - needs to be taken account of in terms of corporate brand positioning. Clearly, the identity of BP (its key organisational attributes) are no longer quintessentially British, but perhaps the brand heritage of $\mathrm{BP}$ was so strong, and the British prove- nance of BP so long, that this was understandable. Moreover, this made the corporation vulnerable to being accused of being British by those who, for strategic reasons, wished to appropriate the brand crisis. Tellingly, perhaps, in late July 2010, the very British CEO of BP, the much maligned Tony Hayward, was replaced by Rupert Dudley, an American, who came across as 'a regular guy' in the United States just as Hayward was seen as 'a regular chap' in the United Kingdom but clearly not in the United States. Currently, there is also talk of BP reintroducing the Amoco brand in the United Sates in order to re-assert BP's US roots and credentials.

Therefore, we should not discount the importance of perceived country of origin effects: the British Monarchy nearly fell when, during the First World War (1914-1918), it was perceived to be German; it had a Teutonic-sounding dynastic name (Balmer, 2009a).

Finally, we should perhaps also note that corporate brand catastrophes can be appropriated by others to serve their own ends; it is a form of corporate brand hijacking.

(d) Place, distance and power may determine whether Corporate Brand Catastrophes are assimilated and become part of global collective memories.

The Piper Alpha Oil Rig disaster of 1988 is virtually unknown in the United States and, apparently, there has not been a single recounting of it in the US media. This is curious because it was the deadliest oil disaster ever, with 167 oil workers dying when the US-operated oil rig blew up: 11 died on the Deepwater oil rig. Of course, one death as a result of corporate misdemeanour is a painful human tragedy for the families concerned and corporations cannot expect to be beyond 
reproach, no matter how many people die. The annihilation of so many British oil workers was a result of dismal safety standards of operation by the US company. However, unlike the BP incident, the tragedy occurred in British territorial waters and the company was American. Moreover, there is no record of a strongly negative British response to the United States at the time, which is quite different from the current situation (Caldwell, 2010). Place, therefore, might determine the profile accorded to a corporate brand catastrophe and the relative power of the countries and nations involved. The latter might determine whether a brand crisis becomes part of a global collective memory and whether images of the incident are repeated in the media, as per the terrible sight of the drowning and oil-soaked birds in the United States.

(e) Context, power and distance, rather than scale, may determine the response to corporate brand catastrophes.

In the context of the dreadful environmental damage suffered in Alaska as a result of the Exxon Valdez oil spill and the recent BP débâcle in the Gulf of Mexico, the response of western governments and oil corporations to the massive, and ongoing, oil spillage in the Niger Delta (in Nigeria, Africa) is perturbing. The Niger delta spillage is an environmental catastrophe of, arguably, biblical proportions and the facts speak for themselves: over the last half century Nigeria has experienced the equivalent of one Exxon Valdez oil spill per year in the Niger Delta. This lack of awareness/interest may be a result of context: 40 per cent of all crude oil imports to the United States alone come from the Niger Delta (Vidal, 2010); power: the relative power of African administrations apropos that of oil corporations and governments is somewhat weak - unlike the relationship between the US administration and BP; distance: the Niger Delta is a world away from The Hague, Madrid, London, Paris, Tokyo and Washington and brings to mind the maxim 'out of sight out of mind'. The low public awareness of the Niger Delta catastrophe in developed nations is a salient reminder that, in terms of rousing public, political and corporate response, context, power and distance can be more significant than the size and scale of any given disaster.

\section{LESSONS FOR MANAGEMENT}

The BP imbroglio provides a good deal of management insight in terms of corporate brand management. A few of these insights will be detailed here:

1. Take in to account that dissonance between two or more key identity types - a notion that informs Balmer's ACID Test (Balmer et al, 2009) viz: corporate brand identity, corporate identity, communicated identity, conceived identity and so on - can undermine, sometimes fatally so, an organisation. Remember what Enron said:

We treat others as we would like to be treated ourselves. We do not tolerate abusive or disrespectful treatment. Ruthlessness, callousness and arrogance don't belong here. (McNulty, 2006)

2. Bear in mind that corporate brand promises are increasingly under the spotlight and are, periodically, likely to come under intense scrutiny for their veracity. Research undertaken by the consultancy Oxford Metrica has revealed that in any given 5 year period, there is an 82 per cent chance of an organisation being confronted with a corporate disaster, and this is a 20 per cent increase from the 1980s (The Economist, 
2010b): consider the Toyota and Enron débâcles and so on. BP's claimed green/corporate responsibility credentials were trumpeted as recently as 2009 and, understandably, BP's current crisis has caused its statements to come under scrutiny. One Public Relations manager at BP said the following in 2009:

Our aspirations remain absolutely unchanged: no accidents, no harm to people and no damage to the environment. (Randall, 2010)

3. Be sensitive to the actual or perceived links with other corporate or national brands, as these associations can escalate brand crises and heighten the emotional response: the $\mathrm{BP}$ crises have played out very badly in the USA much of it has been, it would seem, self-inflicted, but some of it is attributed to the perception of BP being foreign/alien.

4. Remember that corporate brand catastrophes may be appropriated by governments, politicians, the media and even other corporations to serve their own strategic aims, and account should be taken of this.

5. Take on board that corporate brand positioning is a highly cerebral and strategic activity and should be a CEO and board-level concern. It should not be the sole/primary-preserve of public relations, corporate communications and graphic design professionals; it is the task of senior management to understand and manage their corporate brands, and they should never - never - totally delegate responsibility for this key activity. Of course, corporate brands are not about what companies say but what they do, and modes of operation, values and personnel are critical in this regard: everyone in an organisation has responsibility for the brand. Remember that a marketing - and moreover and importantly corporate marketing in corporate branding contexts - is not so much an institutional function but is, importantly, an organisational-wide philosophy (Balmer, 2009b). Corporate marketing should be the focus of both collaborative as well as individual research endeavours that variously: (a) introduce and outline the nature of corporate marketing (Balmer, 1998, 2001a; Balmer and Greyser, 2003) and (b) place it in the broader context of marketing thought (Balmer and Greyser, 2006).

6. Avoid corporate brand exuberance, that is, where the corporate brand covenant is decidedly aspirational but lacks authenticity: this reinforces point 1 .

7. Be alert that in certain instances corporate brand catastrophes - the corporate personality can be anthropomorphised as being that of the CEO, as per the case of Tony Hayward of BP.

8. Be mindful of stakeholder power.

9. Do not make empty claims, but demonstrate that you are a good corporate citizen: you need to act responsibly.

\section{THE PRECEPTS OF CORPORATE BRANDING: THE CREDIBLE, DURABLE, MEANINGFUL, PROFITABLE AND RESPONSIBLE BRAND}

Reflecting on the BP catastrophe it is apparent to me that a corporate brand positioning should be Credible, Durable, Meaningful, Profitable and (perhaps in light of BP's situation) Responsible. Elaborating on the above, I argue that a corporate brand positioning should necessarily be appraised against a quintet of dimensions. As such, a corporate brand positioning should be:

Credible: reflects reality (grounded in the corporate identity - an entity's defining and differentiating characteristics).

Durable: can be maintained over the long term. 
Meaningful: valued by customers and stakeholders (I hold that emotional ownership of the brand resides with these groups; this is quite different from legal ownership of the brand).

Profitable: of strategic value to the organisation and - in the case of public limited companies - afford benefits to shareholders ('stockholders').

Responsible: takes account of its broader corporate responsibility - perhaps following the precepts of corporate marketing - and responsible in terms of ensuring that the brand positioning is judicious and not imprudent.

\section{'MENS SANA IN CORPORA SANO'}

Finally, in bringing this commentary to a close, I am reminded of what Lord Browne said in 2001 about BP's corporate brand. The Latin adage above is a salient reminder that a healthy mind (mens) is dependent on a healthy body (corpora) and in this case the body is the body corporate. A failure to take account of the above is one example of Brand Indifference.

The curious thing about his observations is that they, de facto, deal with the need to ensure that key identity types are meaningfully calibrated as per the Acid Test. His comments also reinforce my earlier observation that a corporate brand positioning strategy should be credible, durable, meaningful, profitable and responsible. As Lord Browne noted when speaking at the eighth ICIG Corporate Brand Symposium in London:

'Without a clear business strategy, there can't be a clear and credible brand.' (Lord Browne, 2001)

To me, there is much in Lord Browne's statement that is absolutely 'spot on'. However, whereas corporate brand management may begin with a modus operandi (a way of working things out), it needs to end with a modus vivendi (a way of living) and, for oil companies, having a green positioning represents a very high, perhaps preposterous, threshold to attain.

With the benefit of hindsight - and if I might be permitted to add foresight - it is a tragedy that BP did not see the dangers inherent in its actions and in terms of its brand positioning, and which were seemingly misaligned with its espoused green branding credentials. BP's espoused branding strategy floundered and has sunk without trace in very deep waters, apart, that is, from the oil. A pity.

\section{REFERENCES}

Balmer, J.M.T. (1995) Corporate branding and connoisseurship. Journal of General Management 21(1): 22-46.

Balmer, J.M.T. (1998) Corporate identity and the advent of corporate marketing. Journal of Marketing Management 14(8): 963-996.

Balmer, J.M.T. (2001a) Corporate identity, corporate branding and corporate marketing: Seeing through the fog. European Journal of Marketing 35(3\&4): 248-291.

Balmer, J.M.T. (2001b) From the pentagon: A new identity framework. Corporate Reputation Review 4(1): 11-22.

Balmer, J.M.T. (2008) A resource-based view of the British Monarchy as a corporate brand. International Studies of Management and Organizations 37(4): 23, Decision, 47(4): 639-675.

Balmer, J.M.T. (2009a) Scrutinising the British Monarchy: The corporate brand that was shaken, stirred and survived. Management Decision 47(4): 639-675.

Balmer, J.M.T. (2009b) Corporate marketing: Apocalypse, advent and epiphany. Management Decision 47(4): 544-572.

Balmer, J.M.T. and Greyser, S.A. (2002) Managing the multiple identities of the corporation. California Management Review 44(3): 72-86.

Balmer, J.M.T. and Greyser, S.A. (2003) Revealing the Corporation. London: Routledge, p. 29.

Balmer, J.M.T. and Greyser, S.A. (2006) Corporate marketing: Integrating corporate identity, corporate branding, corporate communications, corporate image and corporate reputation. European Journal of Marketing 40(7\&8): 730-741.

Balmer, J.M.T., Stuart, H. and Greyser, S.A. (2009) Aligning identity and strategy: Corporate branding 
at British Airways in the late 20th century. California Management Review 51(3): 6-23.

Bakan, J. (2005) The Corporation. London: Constable. Browne Lord, J. (2001) Keynote address delivered at an International Corporate Identity Group (ICIG) Symposium, London. Unpublished paper.

Caldwell, C. (2010) BP feels the ire of a Machiavelli. Financial Times 12-13 June: 11.

Economist. (2010a) BP and golden parachutes. The Wages of Failure 31 July: 53.

Economist. (2010b) Schumpeter brand rehab. 10 April: 74.

McNulty, S. (2006) Tour of Booty. Financial Times Magazine 3-4 June: 22-25.
Randall, D. (2010) Some inconvenient truths. The Independent on Sunday 13 June: 9.

Vidal, J. (2010) Nigeria's agony dwarfs the Gulf Oil Spill the US and Europe Ignore. The Observer 30 May: 20, http://www.guardian.co.uk/world/2010/may/30/ oil-spills-nigeria-niger-delta-shell.

Professor John M.T. Balmer Editorial Board Brunel University, London, UK E-mail: John.Balmer@brunel.ac.uk 